\title{
Musings on Muslim Women in Wedlock: A Quest through Select Literary Works on the Middle East with Current Trends in India as the Backdrop
}

\author{
Susy Antony* \\ Assistant Professor, Department of English, lqbal College, Peringammala, Thiruvananthapuram, Kerala, India; \\ susieant@yahoo.co.in
}

\begin{abstract}
The paper attempts to explore the plight of women in wedlock in the Muslim world as depicted in literary works on the Middle East with certain recent trends in India as the backdrop. The works discussed are Reading Lolita in Tehran by Azar Nafisi, Princess Sultana's Circle by Jean Sasson and A Thousand Splendid Suns by Khaled Hosseini. The various issues in marriage are dealt with in the context of Iran, Saudi Arabia and Afghanistan in the works discussed. The freedom of Muslim women in marriage is a hotly debated topic even in India as triple talaq is currently in the news. The role of patriarchy, culture and religion in the well-being of Muslim women and the fight-back by women and men form the crux of the paper.
\end{abstract}

Keywords: Cultural Constraints, Divorce, Domestic Violence, Muslim Feminism, Polygamy, Patriarchy

\section{Introduction}

Marriage in Islamic society is a sensitive topic even in the twenty first century. As Muslim women have migrated to different parts of the world, the topic has been in the public eye worldwide. In India, with arguments flying for and against the Uniform Civil Code for all its citizens and very recently the court case regarding triple talaq (divorce voiced thrice in quick succession) have made marriage in Islam the eye of a storm. It finds reflection in literary works based on the Islamic world as the topic is a perennial one universally. Similarly with the popularity of social media, divorce is rendered over the phone as text messages and WhatsApp messages even for minor reasons which have gained notoriety in the progressive world. This paper is an attempt to explore the status of women in wedlock in the Muslim world as depicted in literary works with certain recent trends in India as the back drop. The works discussed are Reading Lolita in Tehran by Azar Nafisi, Princess Sultana's Circle by Jean Sasson and A Thousand Splendid Suns by Khaled Hosseini. The issues of polygamy, disparity in age between the bride and the bridegroom, freedom to choose one's part- ner, domestic violence and sex slavery are dealt with in the context of Iran, Saudi Arabia and Afghanistan in the works discussed. As the role of religion in the well-being of women is very crucial, it is also explored.

\section{The Predicament of Afghan Women}

In Reading Lolita in Tehran, Nafisi details her experiences as a teacher in Iran. Her stint in the Western world first as a student and later as a teacher has reformed some of her views about the status of women in Iran. When the going gets tough regarding the infringement of the freedom of women in Iran by the fundamentalist authorities, she has to quit her university job there. But she wants to take an active role in shaping the future of Iranian women which results in her running a clandestine school from her home in Tehran. As a result, seven bright girls have been chosen by Nafisi to attend classes at her home where they discuss classic literary works from across the world. In these discussions the topic of marriage comes up. The history of

*Author for correspondence 
many aspects of marriage in Iran is traced in the course of the memoir. Though the work received much negative criticism in the Arab world for its alleged neo-Orientalist propaganda, it cannot be denied that Nafisi has come up with a strong portrayal of Iranian women.

In Princess Sultana's Circle, Jean Sasson through Princess Sultana's eyes exposes life of women in Saudi Arabia. Sultana belongs to the royal family and therefore has the voice of a much liberated woman in her country. But her fight against the oppression of women is not easy as she has to face conservative men even in her house hold. Contrary to popular belief, the rich women in Saudi Arabia are not very much better off than their poor counterparts. Issues of forced marriage and sex slavery are prevalent in the country and finds place in the work under discussion. Such practises are most often conducted by misinterpreting tenets of Islam.

In A Thousand Splendid Suns, Afghan born diaspora writer Khaled Hosseini who is based in the US portrays the trials and tribulations in the lives of two Afghan women, Mariam and Laila. It forms a powerful commentary on the status of women in Afghanistan. Marriage at a young age to men much senior in age to women, polygamy and the right to choose one's partner form the crux of the novel. Hosseini not only portrays the plight of Afghan women but also sets down the fight by these women to overcome the difficult situations in which they are placed thus making his novel well balanced in its outlook.

\section{The Intricacies of Muslim Marriages}

Islam is a comprehensive religion which details how one's social, political, religious and personal life is to be lead. Muslims all over the world are supposed to follow the basic tenets of the religion. The Holy Quran along with the hadiths (words and sayings of the Prophet) and sunna (traditional customs and practises of the Prophet) form the basis of their deeds. Religion has a greater say in the wellbeing of women. Most often it is found that the religious texts are misinterpreted to give men an upper hand in the domestic and public lives of women. The strongly patriarchal nature of Islamic societies contributes to the plight of their women.

\section{Polygamy}

Polygamy is an aspect prevalent in the Islamic world which finds a place in the works discussed. It involves having more than one wife at a time. In Islam multiple wives, up to four, are permitted at a time conditionally. But at times the condition is not met and only the advantage of having multiple wives is followed by men which result in trauma for the women involved. The intimacy between a man and a woman is thwarted because the man's love and attention are scattered among his many wives. As for the wife, she cannot consider her husband as her own when there are other claimants to his attention. Thus a sense of possession never materialises in polygamy. The situation in which Prophet Mohammed (PBUH) permitted polygamy also needs to be analysed to understand the practice in its totality.

In Nine Parts of Desire, Geraldine Brooks discusses the Prophet's women. Equal treatment of all the wives is a Quranic instruction which a man who takes multiple wives should keep and it can be seen that the Prophet tried to keep this against his own marked preference for Aisha. It is a well-known fact that the Prophet took on many war widows as his wives to comfort and protect them. The need for expansion of the faith by seeking alliances with diverse clans could also have been one of the reasons for the many marriages conducted by the Prophet. Brooks mentions the fact that a hadith indicates Mohammed's knowledge of the damages polygamy inflicts on women ${ }^{2}$. Even during his illness leading to his death, the Prophet tried to be just to his many wives. But since his other wives knew his preference for Aisha, they gave up their rights to be with the Prophet in favour of Aisha ${ }^{2}$.

In A Thousand Splendid Suns, Mariam's father Jalil has three legally wedded wives with whom he lives in a big house. Mariam is Jalil's illegitimate daughter in his maid, Nana. As soon as the pregnancy is revealed, Nana is packed off to the outskirts of the town. So Mariam comes into the world as a harami (an illegitimate child) and grows up craving for her father's as well as the society's acceptance. Mariam by the hand of fate becomes the second wife of Rasheed as his first wife is no more. Mariam's marriage to Rasheed is a ploy by Jalil and his wives to get her out of their way. So they chose Rasheed who is a resident of Kabul, which is a long way from their town. They seal Mariam's chance of any encounter with them as she is married off. Rasheed is attentive towards Mariam in the beginning of their marriage. Later, when she is unable to sustain her pregnancies to childbirths, she falls from his heart. Rasheed desperately wants a child, rather a son. Mariam cannot fulfil his desire as her pregnancies result in natural abortions.

Later on Rasheed takes another wife, Laila who is much younger than him. The explicit reason for his third marriage is due to Mariam's inability to bear children. Laila is much favoured and preferred by Rasheed over Mariam at the beginning of their marriage. Though Rasheed is pious, he does not stick to the religious tenet of being impartial 
to his wives. He wants his wives to practise seclusion and wear burqa while going out. But he cannot stick on with the principle of equal treatment of his wives. Nor does he abstain from enjoying pornographic magazines. Later Laila also falls from his grace when she gives birth to a daughter. He wants a son and his desire is fulfilled with Laila's second child Zalmai. Now Rasheed becomes completely devoted to his son. His wives do not matter to him at all. They are at the receiving end of his anger often which results in his death at Mariam's hands. Thus it can be seen than Rasheed uses religion for his ulterior motives, in keeping his wives subdued. But the benefits which should rightly go to them are being withheld from them.

\section{Coercions on Young Brides to Marry Old Men}

A common trend in the novels under discussion is the practice of old men marrying young brides. In A Thousand Splendid Suns, Rasheed marries young Mariam upon the death of his first wife. Mariam is coerced by Jalil and his wives to marry Rasheed who is nearly thirty years her senior in age. Mariam takes an instant dislike towards Rasheed when she saw him for the first time at their wedding. But she has no choice but to marry him. Later on he marries Laila who is much junior in age to him. She was fourteen at the time and Rasheed nearly sixty. It can be seen that this is an accepted practice in the country. Rasheed considers it as a favour that he is doing to Laila by providing her shelter and male protection, as her parents got killed in a bomb blast. He even deceives her by breaking the false news of her friend Tariq's death so that she agrees to their marriage.

In Princess Sultana's Circle, we find Sultana attempting to ward off her niece Munira's marriage to an old man named Hadi who happened to be her brother Ali's friend. She takes the help of her husband in confronting her brother about the proposed marriage. Men indulging in such marriages, if confronted by others on the issue, take the aid of religion to validate the marriage. The precedence of the Prophet marrying a very young Aisha is used to ward off any criticism in this matter. This is what happens in Munira's case also. Sultana manages to make her husband interfere on her behalf and her brother asks Munira in front of everyone whether she approves of her marriage to Hadi. Munira remains silent and her behaviour is interpreted as her modesty. A cunning Ali very cleverly recreates a similar situation involving the Prophet and his daughter Fatima where she remains silent out of modesty when asked about her approval in her marriage proposal to Imam Ali? .
In Reading Lolita in Tehran, Nafisi's students discuss the situation where Muslim men crave for very young virgin wives whatever be their age. As sharia (Islamic) laws had the upper hand in Iran, the age of marriage for girls used to be nine. At the beginning of the twentieth century, the age of marriage was changed to thirteen and later to eighteen. This was brought down to eight and a half lunar years after the Islamic Revolution of $1978-79^{7}$. Sharia law took over the existing system of jurisprudence. A reassertion of the Islamic system took place and the first casualty was the status of women. Thus there is a regression of the condition of women in Iran after the revolution. Nafisi could experience the change acutely as she had grown up at a time when things looked bright for women. Her mother also could enjoy a better life than when it came to her children's times. She recollects that there were two women cabinet ministers in her youth. But it was a sad situation after the revolution, when the same ministers had to pay a heavy price for their power with their own lives.

\section{Patriarchal Hegemony}

Male fixation is an important aspect of Muslim lives. The preference given to sons over daughters is evident in Muslim culture. In A Thousand Splendid Suns, Rasheed wants a son very badly. When his wife delivers a baby girl, he slams the gate behind him which nearly hits Mariam and her baby on their return home from the hospital. $\mathrm{He}$ is exhilarated when she gives him a son the next time. Though Muslims try to emulate the Prophet in all ways, they do not follow him in favouring daughters. His sons did not survive infancy. Out of his four daughters Prophet Mohammed was very fond of Fatima who was considered by him as 'a perfect human being'.

The fact that patriarchy holds its sway in the scheme of things in the Islamic world is evident from the way punishment is meted out to men and women in case of adultery or illegitimate affairs between men and women. The conditions set in the Holy Book to enforce punishment in the case of adultery are very stringent. But most often the conditions are diluted and the punishments are adhered to. Even in marriage, the rights of women are very much limited. Only a man can initiate the proceedings of divorce; a woman can ask for divorce only for very limited reasons like impotence of the husband. This power entrusted with men is often used for their advantage resulting in trauma for women. Triple talaq which is debated in India is one such instance where men wield their supreme power against women which will be dealt with later on in this paper. 
The effect of patriarchy seen at its extreme is in Saudi Arabia. Women are not permitted to drive vehicles even in the twenty first century. There are restrictions imposed in the movement of women as they have to take their fathers' or husbands' or brothers' permission to travel outside the country. Even within the country they need a male escort to go out of their homes. So it can be seen that Saudi women are infantilized by the authorities. Their attempts at resistance are often crushed by the authorities with severe punishments. Even in Afghanistan, the situation attains similar proportion as seen in Hosseini's novel. In A Thousand Splendid Suns, Laila tries to dodge the moral police when she goes out alone to visit her daughter Aziza who is in an orphanage. At times, she is unsuccessful and suffers the lashes of the Taliban police. In an earlier instance, Mariam and Laila try to escape from Rasheed's hands. But their attempt is thwarted by the rule that they should be accompanied by a male guardian to travel. They try to get the help of a stranger by paying him money only to be double crossed by him. Thus they are handed back to Rasheed who gives vent to his anger by starving Laila and Aziza. This is to be seen in the backdrop of the fact that the Prophet's first wife Khadija was a business woman. There is no seclusion practised by women at that time. There is selective amnesia among many powerful male followers of the faith when it comes to the basic rights of women. The Holy Quran is quoted out of context to assert the rights of men thereby putting Muslim women in mental as well as physical discomfort.

\section{Denial of the Right to Choose One's Life Partner}

The right to choose one's partner is still a distant reality for the women or rather the girls involved in wedlock as seen in the literary works. In A Thousand Splendid Suns, Mariam has no choice in selecting Rasheed. Jalil's wives together with him coerce Mariam into accepting the alliance. In Laila's case, she is tricked into her marriage with Rasheed following the false news of her lover's death. In Princess Sultana's Circle, Munira falls prey to the whims of her father to marry her off to his friend who is in no way a suitable partner to his daughter. It can be seen that these marriages have nothing to do with affairs of the heart. They are just arrangements to cater to certain people's greed. Financial gain is a major factor in forging such alliances. Creating powerful alliances is another reason or else the family wants to get the girl out of their way which is seen in Mariam's case. Laila's case is a complex one. Rasheed wants a young bride to bear him a son. In Munira's case, her father wants to strengthen his friendship with Hadi by offering him his daughter. Only in Laila's case, she desires her marriage to Rasheed to some extent as she badly needs a husband to cover up her pregnancy as a result of her relationship with Tariq.

In Reading Lolita in Tehran, Nafisi traces the history of the deterioration of women's right to choose their partners in Iran. She states that her mother could marry the man of her choice. Nafisi also managed to make her choice in marriage which took place at the eve of the Iranian Revolution. Her sister had still less choice. But she expresses her doubt when it comes to her daughter's marriage. Interestingly the question of individual freedom in marriage which was raised in her class while discussing Jane Austen's Pride and Prejudice has become a reality in Iran after the Revolution. Many progressive women supported the Revolution because they felt that their status would improve once it is through. But there was a sort of regression with the repeal of the family laws. In the 1960s, women in Iran enjoyed greater freedom than in the years which followed the Revolution. There were women cabinet ministers and more women elected to the Parliament. All these changed after the Revolution when these women ministers had to pay a heavy price with their lives. This was achieved by falsely accusing them of warring with God. The struggle for a decent life for the Iranian woman did not stop with that. There were many women protesting against the new laws. Nafisi finds it disheartening that the Revolution which came in the name of the past has done so much damage to the dignity of women ${ }^{7}$. The women took active part in the revolution thinking that their dignity will be upheld but their condition worsened.

\section{Gender Disparities in the Legal System}

Illegitimate affairs are handled with different norms for men and women as seen in A Thousand Splendid Suns. Jalil though married, when caught in an affair with the servant does not lose his dignity. He gets away with the excuse that Mariam's mother, Nana forced herself on him. But it is not the same for Nana. She is shunned by the main stream society. She continues to live in the outskirts of the town and delivers Mariam. She does not attempt to get back to Jalil's house hold. When Mariam attempts to barge her way into Jalil's house she is rudely awakened to the truth that she is different from Jalil's legitimate children. Though Jalil lavishes his attention on her when he visits Mariam in their hut, she is certainly not welcome in his household. Even when she dared to go to Jalil's house, she has to stay out- 
side the gate and is admitted into the house after some time only because Jalil is very careful about his reputation. The conditioning of even women in the society is such that the offences of men are diluted whereas the women involved will bear the brunt of the harsh societal norms. It is this mind set which makes Mariam forgive Rasheed when she comes across pornographic magazines in his room in spite of his hypocrisy to cover her with burqa banishing her from the eyes of the world when she gets out of their home. Similar is the case of Princess Sultana's nephew in Princess Sultana's Circle when caught for torturing a female slave bought from Pakistan. The boy's mother is willing to forgive her son saying that men have their sexual needs. There is another instance in the work when Sultana stumbles upon a harem of her cousin. Many female slaves were held captive there. Though sex slavery is legally banned in Saudi Arabia, many rich men maintain secret harems. When confronted with this issue, the wife of the cousin is not troubled at all by her husband's deeds. The issue of sex slavery is quickly hushed under the carpet with minimal harm to the men involved. Sexual promiscuity in the case of men is often pardoned but in the case of women punished severely in the Muslim community as they fear female sexual promiscuity will lead to chaos in society.

\section{Spousal Sadism}

Domestic violence is another aspect of marriage though not exclusive to Muslim marriages. The difference though is most often the legal system in the Islamic world considers it a family matter and rarely interferes or even if such cases are brought to court the men walk out unpunished or with minimal punishment. Mona Eltahawy in Headscarves and Hymens: Why the Middle East Needs a Sexual Revolution highlights certain instances where women are not given a chance to resist domestic violence ${ }^{4}$. She narrates how a thirty three year old Lebanese teacher Manal was bludgeoned by her husband with a pressure cooker after he accused her of having committed adultery. His sadistic nature comes to the forefront when he calls up Manal's mother and makes her witness her daughter's struggle for life. According to Lebanese media report, the police refused to interfere as it was a matter within the family. Following Manal's death, the victimizer is to stand trial $l^{4}$. If such a crime happens in Saudi Arabia, the husband will escape without punishment as the law there does not punish a husband for murdering his wife though rape and murder are punishable by death otherwise. Eltahawy points out to the Egyptian penal code which 'allows a man to beat his wife with "good intention"4
The good intention is open to broad interpretation by judges if such cases are taken to court.

In A Thousand Splendid Suns, Mariam most often bears the brunt of Rasheed's anger especially after her inability to deliver children. Once she is made to chew pebbles from the yard because the rice she cooked was not what he liked. Both Mariam and Laila are punished severely when they are returned by the police after their failed attempt to get out of the country. Laila is at the receiving end of Rasheed's ire yet again when he comes to know of her meeting with her friend Tariq. But Rasheed escapes any sort of punishment before law. Thus domestic violence is an ugly reality in many Muslim homes.

\section{Seeds of Dissent}

Attempts have been made by not just Muslim women but Muslim men also in improving the condition of women. These progressive minded people have inspired Islamic feminism at varied levels. Notable women activists among them are Nawal El Saadawi and Fatima Mernissi. They have attempted gyno-friendly interpretations of sayings in the Holy Book which have gone a long way in giving dignity to women. In Saadawi's work, The Hidden Face of Eve, she traces the history of struggle for the women's cause offered by Muslim men ${ }^{3}$. Notable among them were Gamal El Dine El Afghani, his disciple Ahmed Fares el Shidyak, Rifa'a Rafi'I El Tahtawi, El Sheikh Mohammed Abdou and Kassim Amen. These thinkers came up with progressive ideas as early as the second half of the nineteenth century and the beginning of the twentieth century. Sheikh Abdou supported the cause of women by vehemently attacking many male-centred practises like polygamy, divorce and sex slavery. The need to provide education to women for the overall development of Arab people was agreed to by all these thinkers. They based their arguments within the framework of the teachings of Islam but most often they were exposed to criticism and attacks from the religious authorities and others within the community ${ }^{3}$.

Margot Badran, in the Introduction to her work Feminism in Islam: Secular and Religious Convergences points out to the fact that Muslim feminist movements whether secular or Islamic have always based their arguments within the framework of the religion ${ }^{1}$. Religious principles form an integral part of the liberation which Muslim women intend to achieve. This is true in the Indian context also as recent developments in India regarding divorce matters show. Many Muslim organisations which have come to the forefront in their fight against triple talaq 
are trying to uphold the dignity of women within their religious space. All these stress the importance which Muslims give to their faith.

In the works taken up for discussion, fight-back by women happens though they have constraints due to the existing system in their respective countries. In A Thousand Splendid Suns, Mariam hits Rasheed dead with a shovel when he attempts to suffocate Laila. In Princess Sultana's Circle, the Princess raises her voice against her nephew's atrocities against a slave girl. She even takes the help of other women in her family to help out women in distress. In Reading Lolita in Tehran, Nafisi has high hopes for her women students as she believes that her students will be visible in the Iranian public space just like the women cabinet ministers of her youthful years.

\section{Divorce in Islam - Current Issues in India}

In a country like India which is multi-religious in nature, there have been heated arguments favouring and opposing a Uniform Civil Code for some time now. Further the issue of triple talaq has been taken up by the Supreme Court. As triple talaq is a gross infringement upon the right of women, many Muslim women's organizations have come to the fore front in their fight against this injustice. All these point to the fact that people, especially women are becoming increasingly aware of their position in family and as an extension, in society. They are unwillingly to accept what comes their way, if it tramples upon their basic rights. This awareness will go a long way in harnessing the much needed strength for Muslim women to counter the atrocities meted out to them in the name of religion by a section of their own men. In India, the situation is much better than in certain Middle Eastern countries because of the vast number of educated women among their lot. But it is a significant fact that many Islamic countries have banned triple talaq by law whereas in India, it is still being debated. Interestingly the All India Muslim Personal Law Board (AIMPLB) favouring both polygamy and triple talaq in an affidavit filed in the Supreme Court of India, has agreed on court that it is a sin but since it is being followed by many it cannot be changed by the court all of a sudden. The AIMPLB justifies polygamy and triple talaq on the ground that 'men are better than women in controlling their emotions and do not arrive at hasty decisions's. This attitude reflects the craving to hold on to male-favoured customs at the expense of trampling on the dignity of women. The Muslim Board has very reluctantly agreed to the Supreme Court to instruct the priest conducting the marriage to advise the bridegroom not to resort to triple talaq if the marriage fails. It is to be noted that the authority has not agreed to issue an order to this effect but merely an advice which the men involved can easily choose not to follow.

\section{Is there a Way Out?}

Muslim women are kept submissive and usually do not react to the atrocities committed against them. The reasons for such behaviour are multifarious. The education of women was suppressed for a long time. As a result they are unaware of the advancement even within their community worldwide. Financial dependence on the spouse is another fall out of illiteracy and unemployment. Even among working Muslim women, many do not have the freedom to handle money. They are expected to work outside and be a perfect wife and mother in their families. They are conditioned for centuries to be submissive to the men in their families whether it is the father, the husband or even the sons. Economic independence will help Muslim women in their fight against oppression to a great extent.

Most often women themselves are to blame for their plight as they accept the conditions set down by the patriarchal society without questioning them. They accept the norms unconditionally as centuries of conditioning have made Muslim women passive to the atrocities committed against them especially in marriage. They are often oblivious of their rights in the marriage contract drawn as they are waylaid by romantic notions of marriage. It is possible to set down conditions against polygamy and also right to initiate divorce in the contract at the time of marriage. Such options within the religious frame work should be utilized to benefit Muslim women and also to protect them from the atrocities which could be committed against them after marriage. Muslim women should familiarize themselves with the religious texts so that they cannot be tricked by male-friendly interpretations which are in circulation. A thorough knowledge of the religious texts will go a long way in improving the condition of Muslim women in wedlock.

\section{Conclusion}

The empowerment of women should start from home. No outside force can bring about the desired changes in the lives of Muslim women. Mariam and Laila in $A$ Thousand Splendid Suns have initiated the change in their lives which give hope not only to Laila and her daughter Aziza but also to the Afghan women in general. Similarly Sultana has taken a bold step in helping hapless women get out of the rut of sexual slavery in Saudi Arabia. Nafisi has 
influenced many Iranian women to think out of the box. These courageous steps portrayed in literary works will no doubt inspire women to voice their opinions boldly, whatever tough situations they have to encounter in their lives. Though Muslim women's issues may appear different in different countries, there are certain underlying similarities to it. Most of them stem from the strongly patriarchal culture in which they are rooted in. A male-centred interpretation of the religious texts to please Muslim men adds fuel to fire. Gender-sensitivity should be inculcated among the youth so that they take a broad view regarding the status of women in marriage. For such a move, a collective effort should be made by the educated women along with the progressive men among them to enhance the quality of lives of Muslim women.

\section{References}

1. Badran M. Feminism in Islam: Secular and Religious Convergences. London: One World; 2013.
2. Brooks G. Nine Parts of Desire: The Hidden World of Islamic Women. London: Penguin; 1995.

3. El-Saadawi N. The Hidden Face of Eve: Women in the Arab World. Hetata S, editor. London: Zed; 1980.

4. Eltahawy M. Headscarves and Hymens: Why the Middle East Needs a Sexual Revolution. London: Weidenfeld \& Nicolson - Orion; 2016.

5. Hosseini K. A Thousand Splendid Suns. London: Bloomsbury; 2008.

6. Mernissi F. Beyond the Veil: Male-Female Dynamics in Modern Muslim Society. Bloomington: Indiana UP; 1987.

7. Nafisi A. Reading Lolita in Tehran. London: Harper Perennial; 2008.

8. Rajagopal K. Islamic Law Anglicised: Centre. Hindu. 2017 May 16; Thiruvananthapuram.

9. Sasson J. Princess Sultana's Circle. London: Windsor Brooke; 2002. PMCid:PMC1222402 